\title{
Perception of the Family Health Team on the care of drug users
}

\author{
Percepção da Equipe de Saúde da Família sobre o cuidado a usuários \\ de drogas
}

Laís Santana Santos Pereira Lira', Luana Machado Andrade², Luma Costa Pereira Peixoto² , Sâmia de Carliris Barbosa Malhado², Edite Lago da Silva Sena²

DOI: 10.1590/0103-1104202012507।

\begin{abstract}
Study aiming to understand the perception of the Family Health Strategy team about on the care of drug users. This is a phenomenological study in the approach of Maurice Merleau-Ponty, conducted with nine professionals from a Family Health Unit in the interior of Bahia, Brazil, from January to March 2012, through the open interview related to reading of Drawings-Story with Theme produced by the participants themselves. The comprehension of the descriptions occurred through the Ambiguity Analytical technique, which originated two thematic axes: the belief in the existence of a space for the insertion of the drug user; and the belief that the user is outside society. Thus, looking at the user as someone who looks from the outside, without intertwining with him, contributes to segregation and social exclusion, which requires professionals to suspend theses that they support in the field of drug use and resignification of the way they see and take care of the drug user and his family.
\end{abstract}

KEYWORDS Professional-family relations. Street drugs. Health knowledge, attitudes, practice. Family Health Strategy. Philosophy, nursing.

RESUMO Estudo com objetivo de compreender a percepção da equipe da Estratégia Saúde da Família sobre o cuidado a usuários de drogas. Trata-se de estudo fenomenológico na abordagem de Maurice Merleau-Ponty, realizado com nove profissionais de uma Unidade de Saúde da Família no interior da Bahia, Brasil, no período de janeiro a março de 2012, por meio da entrevista aberta relacionada com a leitura de Desenhos-Estória com Tema produzidos pelos próprios participantes. A compreensão das descrições ocorreu mediante a técnica Analítica da Ambiguidade, que originou dois eixos temáticos: a crença na existência de um espaço de inserção próprio do usuário de drogas; e a crença de que o usuário está fora da sociedade. Assim, olhar o usuário como quem olha de fora, sem se entrelaçar com ele, contribui para a segregação e a exclusão social, o que requer dos profissionais a suspensão de teses que sustentam no campo do uso de drogas e a ressignificação da forma como veem e cuidam do usuário de drogas e sua família.

PALAVRAS-CHAVE Relações profissional-família. Drogas ilícitas. Conhecimentos, atitudes e prática em saúde. Estratégia Saúde da Família. Filosofia em enfermagem.

\footnotetext{
1 Instituto Federal de Educação, Ciência e Tecnologia (IFBA) Eunápolis (BA), Brasil. lailira@hotmail.com

2 Universidade Estadual do Sudoeste da Bahia (Uesb)

- Jequié (BA), Brasil. 


\section{Introduction}

Drug policies formulation in Brazil, initially, took place in a repressive perspective, which criminalizes the use and the user and promotes a stigmatizing and prejudiced culture in society, becoming a model of prohibitionist care' ${ }^{1}$. This perspective implies making it difficult for people who suffer from habitual drug use to access therapeutic devices, resulting in an impact on family members $\mathbf{2}^{\mathbf{2} 3}$.

The logic of care based on Harm Reduction (HR) emerges as a model that seeks to recognize the user's singularities and aims to reduce the losses and damages resulting from habitual drug use, guarantee users' rights and promote health and citizenship ${ }^{\mathbf{1}, \mathbf{4}}$. In addition, the policies formulated with this proposal highlight the challenging issue of family care.

In 2003, the Attention Policy to Users of Alcohol and other Drugs was formulated, within the scope of the Psychiatric Reform and the Unified Health System (SUS), which understands that care must happen through networks of health services and articulated social networks ${ }^{5}$. In 2005 , still with a repressive character, the National Drugs Policy was enacted, bringing aspects related to the strengthening of the inclusion of some services and social segments in the care process, such as the church, commerce, friends, Psychosocial Care Centers (Caps), therapeutic communities, self-help groups, Primary Care (PC), among others ${ }^{6}$.

Within the scope of PC, the Family Health Strategy (FHS) was implemented as a possible space for the development of actions that guarantee access for all people in an equal and equitable way. From territorialbased care devices to an enrolled population; such as bonding, listening, welcoming, comprehensiveness, equity, social participation and coordination of care; the FHS has the potential to care for contexts that suffer from habitual drug use. Thus, these characteristics make it an appropriate model for the proposal of drug policies.
In contemporary society, faced with the functional and structural changes experienced in the family, the existence of a drug user, which, in our study, we are referring to as a 'regular drug user', is a reality that is difficult to face. When this happens, not everyone is able to deal with the situation, which causes a series of difficulties in order to face the problems arising from it, mainly due to the feeling of unpreparedness and the cultural construction of exclusion, stigma and prejudice, which requires changes in posture on the part of health professionals?

Many FHS professionals, although they recognize their responsibility for care in the context of the consumption of alcohol and other drugs, do not develop actions in this specific field, which underutilizes the caregiving potential of the FHS in the face of families that live with the losses resulting from drug use. This may be occurring, mainly, due to the team's unpreparedness to deal with situations of suffering and, also, due to the moral concepts and stigmas related to the theme ${ }^{7}$. Thus, the perception of oneself as a potential caregiver of those who suffer from habitual drug use and with inexistent or inadequate care actions makes us understand the ambiguity that permeates human experiences.

In fact, the health experience is not about building objects/objectivities, but about configuring subjects/intersubjectivities. Health management never occurs in an isolated, strictly individual way, but must always be built on, with and for intersubjective interactions, from immediate relationships to those in which we participate with mediation of culture and institutions ${ }^{8}$. Thus, it becomes justifiable and inevitable to bring to light the perception of professionals about the care of habitual drug users, considering the transforming power of the interaction between professional subjects and subjects to be cared for, in order to produce knowledge that goes beyond health care.

Unfortunately, in most approximation attempts, we are faced with the productive 
potentiality of care of FHS professionals being restrained by cultural and subjective issues, which make it impossible to open up to a real encounter with the user, which increases the suffering in their family members. The connection lines that should form the care network for habitual drug users, and their families, are increasingly weakened ${ }^{9}$.

Based on this scenario, the present study aims to understand the perception of the Family Health team (EqSF) about the care for habitual drug users. We understand that the professionals' knowledge, marked by prejudices and stigmas, interferes in the way they develop their interventions and limits the possibilities of care for the user and families?.

In this study, assuming that the perception of the FHS team about the care for drug users can lead the way they develop their interventions, we believe that, from the intersubjectivity that permeates the field of research/service, we will be able to understand the perception of the team FHS on the care of drug users, opening the possibility to reframe the theses and transcend them to a new way of acting/caring in the face of the habitual use of drugs that includes users and their families.

\section{Methodology}

Because it is a study that starts from an experiential experience and aims to unveil perceptions and senses, we chose to base it on the approach of Maurice Merleau-Ponty, whose perspective essentially consists of describing the ambiguities inherent in the perceptual experience. Thus, we consider the author's statement:

everything I know about the world, even through science, I know first from my point of view or from an experience of the world without which the symbols of science would be meaningless ${ }^{10(18)}$
The research was carried out in a municipality in the interior of Bahia, Brazil, with $100 \%$ coverage of the FHS, with nine participants, with one representative of each professional category of the FHS team: the Doctor, the Nurse, the Nursing Technician, the Community Health Worker (CHW), Dentist and Dental Office Assistant (ACD). This team is defined in accordance with

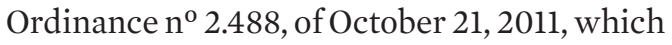
approves the National Primary Care Policy, establishing the revision of guidelines and rules for the organization of PC for the FHS and the Community Health Agents Program (Pacs). In addition to these participants, other FHS workers were included, such as the Administrative Assistant, the General Services Professional and the Municipal Guard, because we understand that care is not a specific and exclusive role of the health professional, but it is revealed as a possibility in all relationships, which do not exclude other professionals.

After approval by the Research Ethics Committee of the Southwest Bahia State University (CEP/Uesb), under n ${ }^{\circ}$ 191/2011, the experiential descriptions were constructed through an open interview in relation to the Story-Drawing with Theme, carried out by the participants themselves. The description of the experiences was carried out in the unit itself, with each professional separately during times of low frequency.

Story-Drawing with Theme is a projective technique, and its application in the present study consisted of employing an indirect means of expression, justified by the ease of leaving the informant free for more spontaneous communication and because it is an investigatory research mean ${ }^{11}$.

Each informant was instructed to draw, on a blank sheet of paper with colored pencils, a drawing following the orientation: 'make a drawing related to the care of families of drug users'. Then, we conducted the interviews, asking each one to tell the story of his/her drawing orally; moment they were recorded. 
The interview script included identification data and three guiding themes: tell me about the drugs issue in your professional context; comment on the actions that your team develops in relation to the families of drug users; what is your perception about caring for drug users families?

The understanding of the descriptions that have emerged from the interviews occurred through the Analysis of Ambiguity. This strategy allows for the different profiles that emerge from the experiences of the research participants in the light of the phenomenological approach of Maurice Merleau-Ponty, and can be applied in studies with other approaches that focus on human perception, considering that this reveals itself as something ambiguous ${ }^{12}$.

\section{Results and discussion}

Through the bond established in the meetings with the workers, the immanent ambiguity was shown in the intersubjective experience, becoming transcendent. Based on MerleauPonty's notion of intersubjectivity, we understand that the experiential descriptions produced with the participants result from the intertwining of the sensitive world (feelings) with the socio-cultural world (rationality) ${ }^{9}$. Therefore, the descriptions unveiled the conflict between feeling and thinking, between what was not possible to deliberate and the concern to develop and issue a technical, academic response, which included what was addressed in the interview ${ }^{\mathbf{1 0}}$.

From our experience, we were able to point out two of the main theses: the first consists of the belief that society is separated into two sides: the good side and the evil side, with the drug user being inserted on the evil side, and the rest of society, including technicians, on the good side; and the second is based on the belief that there is an objectification of the world of drugs, as a world outside and separated from society, reinforcing the idea that the user is outside it. These led us to understand that the way the team of workers sees families and their contexts interferes in the way they care, reinforcing the MerleauPonty's thinking that, in the cultural universe, the incorporated theses mobilize human feelings and conduct ${ }^{10}$.

Based on the first thesis, emerge from the experiential descriptions, from the intersubjective experience, the social beliefs dichotomized on two sides: the good side and the evil side

[...] and then he buys, sells, he liked it the first time, sold, made the money and everything, so 'here is good, this is the way', and this is where he deviates to that bad path. That's it! (ACD).

[...] there were three of us, and he was the only one who went to the addiction side, to the nastiest side and went to São Paulo, got there, lost his brother who was addicted to drugs. (Administrative Assistant).

The description of the ACD makes the 'world of drugs' to be seen as the 'bad path' to which the user deviates, and the Administrative Assistant refers to this world as the 'addiction side' or the 'evil side', which configures it as an objectified place and separate from society. In the light of Merleau-Ponty, regarding perception, these descriptions are shown in a figureground perspective, since, when bringing the idea of a 'evil' world, the professional places himself as an observer belonging to the "world of good' and immune to drugs.

Situated at the objective pole, research participants tend to stay away from the world of drugs as a condition that keeps them immune to all the challenges that engender this process. However, escaping this dualism - good and bad - that is present in science itself, objectivist and subjectivist, the ontology of the MerleauPonty's experience takes up in the speeches the "layer of living experience through which the other and things are first given to us, the system - Self-others-things - in the nascent state"10(89-90). 
Through intersubjectivity, in which subject and object merge, the intertwining between human beings and all other living beings, we are led to understand the dynamics of the perceptual experience that this dichotomy presents, not just as a struggle between right and wrong, but as an ambiguity factor of our existence in the world. Even though the health worker exercises his/her role for the care of the drug user (what is shown), he/she remains outside the observed world; and the user becomes the other, from a world to which he/she does not belong (what he/she feels).

Thus, the subject does not develop any bonds of interest, emotion, meaning or value with things in this world ${ }^{\mathbf{1 3}}$, which strengthens the polarity between the professional and the user. Let's see the following report:

To me, he found God, he had the courage to look for God, he will leave, the greatest strength, isn't he? Friends are supportive, God is bringing 'come to my side, my son', and everything is solved for me. (Dentist).

When stating 'he will leave', the Dentist seems to announce that, to be on the side of God, here understood as the 'side of the good', the user needs to move from somewhere that, until then, makes him/her free from the presence divine. This place, conceived from a stigmatizing perspective as the 'world of drugs', is located outside of society, that is, in a space in which the professional believes himself not to cohabit. Looking from the outside point of view, this polarity can be a limit for the team's involvement with this world, since it sees it as an 'dismantled' environment, as shown in the following report:

This is what is happening, the demand only increases, the age group only decreases, consumption increases more and more, because of this, some patients really develop a severe psychotic condition and become non-functional. Young people are not able to restructure their lives, they are not able to enter the job market, they are not able to, there is a disarticulation, thus, of the world, of their world [...], even because they did not find the right job, an environment that did not see another validity, didn't see other worlds, it was very difficult. (Doctor).

The description reveals the 'world of drugs' as an 'environment in itself', and the fact that the user belongs to this world makes it 'nonfunctional', preventing it from 'restructuring life'. From this understanding, we can think that the fact that the labor market does not admit people involved or who have already been involved with drugs may be related to the stigma surrounding this context, always conceived as a 'bad world'. In this perspective, using drugs constitutes an anti-civilization process, a deviation from the development projects of a civilized society, in which collective security must be predominant ${ }^{14}$.

Even when abstinence seems to be the maximum expression for the adjustment of the subject, for purification and for the social acceptance of the user, the character of vigilance can remain eternal. For Merleau-Ponty, perception is something that flows in time, taking up the lived and flowing with each new instant. Thus, we are always dealing with three dimensions, past, future and present, which are also different poles for thinking about the experience with the other ${ }^{10}$. It turns out that every construction produced by the social imaginary is present in our lives; and, as such, even if it becomes a past (something that has been taught to us since childhood), "it sticks in time like a wedge and claims to eternity"10(526).

When we return to this past, full of stigmas and prejudices, it is necessary to make an effort to update and reframe it. This possibility of change is amplified when it is exposed to the other (intersubjective relationships) and wishes to understand, and no longer judge the other different from me and the 'other self'. When this does not happen, as professionals reinforce (eternalize the past apprehended in time) the 'disease' caused by the use of drugs as something incurable, even if it can be stabilized, it will always be 
present, as a stigma, an anguish, an unreachable mystery ${ }^{\mathbf{1 4}, 15}$.

Thus, the study shows that the eternal subjection to the possibility of the user to present recurrence inscribes him as someone who cannot be trusted, which contributes to the passivity, exclusion and weakening of the user's social organization, as expressed by the professional a follow:

Besides, whenever one enters the world of drugs, it is a world of temptation [...] And then what happens? The young person enters the world of drugs, trickery, violence [...]. (General Services Professional).

The description reveals a deterministic, moralistic look regarding the context of insertion of the drug user, calling it the "world of drugs'. Thus, it directly associates it with perdition, theft, traffic, crime and violence, which echoes the objectified view that the team has about the subject. The constitution of this world as an object with which health workers do not mix does not establish relations, it prevents the subject from opening, the user of the service, to 'another self', as Merleau-Ponty points out:

I alienate my perpetual power to give me 'worlds' for the benefit of one of them, and for this very reason this privileged world loses its substance and ends up being just 'a certain anguish'10(124).

The second thesis evidenced in the study is based on the belief that there is an objectification of the world of drugs, as a world outside and separated from society, reinforcing the idea that the user is outside it. Let's see, below, the manifestation of the professionals:

[...] today she lives outside the drug environment, right? She built a new family, father and mother and very happy brothers, and formed a family, and today he is a good person in society. (Nursing Technician).
[...] and today he is 23 years old, got a job, has a family, left the world of drugs and did well in society. (Nurse).

The descriptions show the various profiles in relation to the user and that the figure always has a background; and everything that is perceived as a figure on a background is part of a field, the idea of pure perception being inconceivable, that is, when figuring a landscape, we will never have specific perceptions, "while the whole collection of these becomes 'vision', and forms a picture before us"10(10). The professionals consider that the condition to be part of society is to be 'outside the drug environment', which reinforces the objectification of this context. Thus, the team reveals a strong historical influence of prohibition, a model in which there is no tolerance for drug use, which creates an obstacle for users to access health services or other places where they can seek help $p^{7,14-16}$. Furthermore, the following expressions express the ambiguity of the perception about the drug user:

The difficult thing is to find God in relation to this person because he is in the underworld, he is abandoned, he is alone, with no future perspective in life. (Dentist).

\section{[...] but a really drunk guy, drugged, is really out} there playing [...]. (CHW).

The use of words and expressions, such as 'drug addict', 'alone', 'drunkard', belonging to the 'underworld', 'uncared for', show the objectivist vision of professionals, characterizing the user as someone deprived of building life projects, which limits the possibility of communication and the potential to experience the transcendence of experiences in the user-health professional relationship.

Difficulty in 'finding God in relation to this person' dehumanizes the user and places his/ her life as something that is determined by habits, ways of being, dependencies and illnesses. The future, as something palpable 
and predictable, becomes 'without perspective' and once again ambiguity is present and makes us understand the distortions of the models implemented in our health system. The phenomenological analysis, in turn, allows us to recognize the undetermined as a positive phenomenon and to think about possibilities for effective changes that come from the subjects and not from the models ${ }^{10}$.

Likewise, this objectivist view makes the drug user's stigma more lasting than the substance's own effect on the organism, which stamps and imprisons the subject on the addict's character, making it a status of truth that often makes it impossible for him to experience their differentiation ${ }^{\mathbf{1 3}}$. In this context, Merleau-Ponty puts us the following reflection on sociocultural relations:

Obsessed with being, and forgetful of the perspectivism of my experience, I henceforth treat it as an object and deduce it from a relationship between objects ${ }^{\mathbf{9}(108)}$.

Thus, let's see the following statements:

$[\ldots .$.$] because these people who use drugs, unem-$ ployed people start to steal things inside their own home, then when there is nothing else at home that they can really look for outside, they sell the things they have, sneakers, T-shirts. Then when there is no other resource, what will they try? Stealing. (CHW).

Young people, more from society, because if I sell drugs, if you belong to society, you will get it to support drug trafficking. (Municipal Guard).

Here the user appears as a 'thief' who steals his/her own family, which reinforces the process of marginalization experienced by this subject. Seeing themselves as part of the drug-free world, the team does not recognize itself as equal to the user, transforming it into an object, and this "individuation of the object appears as the expression of a positional power"10(109), which immobilizes the perceptual experience. The association between drugs and marginality is a mechanism that deflects the responsibility of the State, bringing to the user the feeling of guilt for use and embarrassing suffering, which does not solve the problem of trafficking, in addition to further distancing users from health services, since guilt does not prevent him from using the drug ${ }^{\mathbf{1 4}}$. The position of the professional, in the role of judge, can also be configured theft or procedural death since he limits the opportunity for the user to become another. Stigma as a negative status adheres to the citizen's skin, making secondary their other constitutive characteristics and social roles, which increases discrimination and promotes the person's social death, preventing them from seeking their place, from projecting into the future or to create life expectations, in addition to depriving it of personal growth and the achievements arising from the relationships experienced in society ${ }^{13-15}$. In the light of Merleau-Ponty, we understand that the human being constitutes an I can, which means to say that he/she is in constant transcendence. Therefore, stigmatizing the subject corresponds to the negation of the inherent potency. The philosopher says that "the scientific representations according to which I am a moment in the world are always naive and hypocritical"10(4).

The perceptual experience operates through the set of senses and connection with the world from the various dimensions of the body itself. This is not as a physiological body, but as a porous flesh that becomes our vehicle of being-in-the-world and that flows in time, resuming the experiences and draining away with each new moment ${ }^{10}$.

There are, for the philosopher, some dimensions for the expression of this body; and in all of them, when there is a blockage of its manifestation, in a cascade effect, a kind of 'effacement' of its potency occurs. The possibilities of being, undoing 
and redoing are 'blocked', and both users and workers remain in a state of freezing, impotence and reproduction in the same ways of being that led them there - users in search pain relief, and workers promoting health (non)care.

Despite paradigmatic changes in the context of coping with habitual drug use, the health team still values moralistic and disciplinary treatment, as shown in the following reports:

As you see in many clinics here, you take the patient, you get there, you drop him in, he stays if he wants. You have to have everything walled up, all well done [...] It's good stuck, locked, walled, when you get out of there 'Oh, I'm in heaven, I'm out here', when he gets here outside he will not do more, because he will say 'Oh, I was there and I was locked up, outside is something else'. (Municipal Guard).

We had a case here of a relative, of friends of people trying to solve it and the solution is to send him out or [...] to another state. (Administrative Assistant).

I would draw a happy family, at ease with life, just peace and joy. Contact with nature gets us better because we breath clean air. It help us keep our heads and minds clean. (General Service Professional).

The descriptions make us see the user as someone who is outside society; and, conceiving it in this way, the team believes that the treatment must also be carried out outside the territory. The descriptions reveal, therefore, that care means removing the user from society and disciplining him/her, in the form of moral treatment. This, in turn, appears as a characteristic of psychiatric rationality, which has maintained the practice of hospitalization as an uninterrupted social and moral control ${ }^{17}$.

In this sense, based on principles of vigilance and punishment, psychiatry aims to keep users imprisoned in mental hospitals, isolated from the world and their daily lives, with institutionalization as a producer of homogeneity and objectification of institutionalized ones ${ }^{\mathbf{1 7}}$.

In fact, the centrality in the hospital and the hegemony of the biomedical paradigm in medical schools still contribute to the inadequacy of the profile of professionals trained in Brazil in our contemporaneity ${ }^{\mathbf{1 8}}$. In this context, the Brazilian Association of Psychiatry, an institution that, since the early 2000s, has taken a strong critical and public position against the Psychiatric Reform (PR), has mobilized paradigmatic problematizations in the area of mental health, favoring professional bio-scientific concepts and practices and based on the market logic of the pharmaceutical industry across civil society ${ }^{\mathbf{1 9}, 20}$. Thus, even after so many years have passed since the beginning of the struggle for PR, challenges are posed every day for those who wish to bring about psychiatric change in mental health care in Brazil. Furthermore, at the same time, we have been following setbacks in public mental health policy by dismantling some of its pillars, which also requires reflections and research in the area, as we still know little about the impact of these setbacks on assistance and socio-cultural productions ${ }^{\mathbf{1 9}}$.

In view of the setbacks in mental health care, we came across managers supporting actions, based on Resolution $\mathrm{n}^{\circ} 32$, of 2017, which changed the Psychosocial Care Network (Raps) and its perspective of substitute services, expanded the offer of hospital beds qualified for hospitalization and readjusted daily rates for subjects hospitalization in specialized hospitals, reflecting a stimulus to psychiatric hospitalization ${ }^{21}$.

Added to the 2017 Resolution is the recent publication of Technical Note $n^{0} 11 / 2019^{22}$, published by the Ministry of Health to explain and consolidate the changes that the PR has been undergoing since 2017 in the National Mental Health Policy and in the National Drug Policy Guidelines. 
Thus, we emphasize the need for the wide dissemination of practices and studies that articulate mental health with collective health, community-based and dialogical, intersubjective and horizontal relations in care approaches, in addition to the biomedical model23. In this perspective, agreeing with the Merleau-Ponty's reflection on intersubjectivity ${ }^{\mathbf{1 0}}$, we understand that the intersubjective meeting between health professionals users and other caregivers, in addition to producing the acceptance of differences, is capable of promoting resignifications of experiences of suffering in comprehensive care approaches for everyone involved in the meeting 24 .

Finally, historically hegemonic models in vertical relations in mental health care can interrupt the perceptual, intersubjective experience and influence ineffective care relationships in the production of life. Thus, in the study, we raised the perspective of possible changes in the professionals' worldview and in the invention of effective prevention, rehabilitation and social reintegration practices, since "So history is neither a perpetual novelty, nor a perpetual repetition, but the unique movement which creates stable forms and breaks them up"9(130).

\section{Final considerations}

The study consisted of understanding the perception of the FHS team about the care for drug users, in the light of the phenomenology of Maurice Merleau-Ponty. For the philosopher, knowledge is built on the intersubjective relationship that is established through dialogue in the dynamics of perceptual experience.

Descriptions related to the first thesis show that professionals understand the context of drug use as an objectified world and a world apart from society, which has been called the 'world of drugs'. By establishing this space as the evil side, the team opposes it, that is, as a member of the good side. Thus, the dichotomy between the world of the team and the world of the user - the 'world of drugs' - interferes in the intersubjective process that should characterize the care relationships between the team and families.

The second thesis presented postulates that the drug user is out of society, inhabiting a space that technicians are not part of. When conceived in an objectified way, the thesis imposes a series of characteristics on it: 'murderer', 'thief', 'offender', 'drug dealer', 'outcast', 'drug addict', 'lazy', 'uncared for', 'drunkard', 'with no life perspective', among other stereotypes.

Looking at the user as someone who looks from the outside, without intertwining with him/her, contributes to segregation and social exclusion, since it hinders access to spaces that can favor other expressions of care, such as the achievement of social interactions and the construction of life projects.

It is essential, therefore, for professionals to understand the theses they support in the field of drug use and re-signify the way they see and care for the drug users and their family. Also, the perception of the FHS team about the care for families of drug users seems to be configured as supposed care or, so to speak, as carelessness, since it is guided by the support of objectivist theses. When they see themselves as different from the user, as members of opposite worlds, the distance between professionals and families interferes with the establishment of dialogical and transforming spaces, which interrupts the perceptual experience, since care is not recognized as a result of intersubjectivity.

By reframing the look, the FHS team can see itself as equal to the other, inasmuch as they are beings of generalities. By enabling spaces for speech and listening, the dialogue between professionals and families will be the means by which new alternatives 
will be discovered to reduce damages resulting from the harmful use of drugs and, thus, new possibilities of existence from the perceptual experience.

From the results obtained, it is noticeable the need for greater approximations between the FHS and Mental Health services, in order to better prepare PC professionals for drug care in a biopsychosocial perspective, through important devices such as matrix support and continuing education.

As limitations of the study, the drawings produced by the participants that consisted only of the use of an indirect means of expression were not analyzed. Their analysis would further enrich the results of the study. In addition, the research was developed only in one FHS unit, and the expansion to other units could reveal other theses to be added to the results.

Finally, the study enabled us to understand that the phenomenon always shows itself by ways of profile, bringing with it other profiles. In the dynamics of perceptual experience, the construction of knowledge constitutes an unfinished experience, and the phenomena are never completely 'revealed', which makes it impossible to reach all their perspectives.

\section{Collaborators}

Lira LSSP (0000-0003-1295-6678)* contributed substantially to the conception and planning or to the analysis and interpretation of the data; significantly contributed to the drafting or critical review of the content; and participated in the approval of the final version of the manuscript. Andrade LM (0000-00028418-9781)* contributed significantly to the drafting or critical review of the content; and participated in the approval of the final version of the manuscript. Peixoto LCP (0000-00026366-0212)* contributed significantly to the drafting or critical review of the content; and participated in the approval of the final version of the manuscript. Malhado SCB (0000-00020651-1835)* contributed significantly to the drafting or critical review of the content; and participated in the approval of the final version of the manuscript. Sena ELS (0000-00021236-8799)* contributed substantially to the design and planning or to the analysis and interpretation of data; contributed significantly to the drafting or critical review of the content; and participated in the approval of the final version of the manuscript. 


\section{References}

1. Sodelli M. Des-tramando o proibicionismo: a redução de danos na prevenção. In: Fernandez OFRL, Andrade MM, Nery Filho A. Drogas e políticas públicas: educação, saúde coletiva e direitos humanos. Salvador: EDUFBA; Brasília, DF: ABRAMD; 2015. p. 125-136.

2. Vipers S, Hayashi K, Milloy MJ, et al. Use of withdrawal management services among people who use illicit drugs in Vancouver, Canada. Substance Abuse Treatment, Prevention, and Policy. 2018; 13(27):2-8.

3. Matsuzaki M, Vu QM, Gwadz M, et al. Perceived access and barriers to care among illicit drug users and hazardous drinkers: findings from the Seek, Test, Treat, and Retain data harmonization initiative (STTR). BMC Public Health. 2018; 18(366):2-11.

4. Gomes TB, Vecchia MD. Estratégias de redução de danos no uso prejudicial de álcool e outras drogas: revisão de literatura. Ciênc. Saúde Colet. 2018; 23(7):23272338.

5. Brasil. A Política do Ministério da Saúde para atenção integral a usuários de álcool e outras drogas. Brasília, DF: Ministério da Saúde; 2003.

6. Brasil. Resolução nº 03/GSIPR/CH/CONAD de 27 de outubro de 2005. Aprova a Política Nacional sobre Drogas. Diário Oficial da União. 28 Out 2005. Brasília, DF: Conselho Nacional Antidrogas; 2005. [acesso em 2020 maio 18]. Disponível em: https://www. legisweb.com.br/legislacao/?id=101642.

7. Paula ML, Jorge MSB, Vasconcelos MGF, et al. Assistência ao usuário de drogas na atenção primária à saúde. Psicol estud. 2014; 19(2):223-233.

8. Ayres JRCM. Cuidado: trabalho, interação e saber nas práticas de saúde. Rev baiana enferm. [internet]. 2017 [acesso em 2020 maio 19]; 31(1):e21847. Disponível em: https://portalseer.ufba.br/index.php/enfermagem/article/view/21847.
9. Subrinho LQ, Sena ELS, Santos VTC, et al. Cuidado ao consumidor de drogas: percepção de enfermeiros da Estratégia de Saúde da Família. Saúde Soc. 2018; 27(3):834-844.

10. Merleau-Ponty M. Fenomenologia da percepção. 4. ed. São Paulo: Martins Fontes; 2015.

11. Trinca W. Formas de investigação clínica em psicologia: procedimento de desenhos-estórias: procedimentos de desenhos de famílias com estórias. São Paulo: Vetor; 1997.

12. Sena ELS, Gonçalves LHT, Granzotto MJM, et al. Analítica da ambiguidade: estratégia metódica para a pesquisa fenomenológica em saúde. Rev. Gaúcha Enferm. 2010; 31(4):769-775.

13. Melo RF, Maciel SC. Representação Social do Usuário de Drogas na Perspectiva de Dependentes Químicos. Psicol. Ciênc. Prof. 2016; 36(1):76-87.

14. Venturi G. Consumo de drogas, opinião pública e moralidade: motivações e argumentos baseados em uso. Tempo Social, revista de sociologia da USP. 2017; 29(2):159-186.

15. Prates JG, Pinho PH, Oliveira MAF, et al. A concepção dos enfermeiros de serviços de urgência e emergência sobre o processo saúde-doença na assistência aos usuários de substâncias psicoativas. Saúde debate. 2014 ; 38(101):318-327.

16. Bard ND, Antunes B, Roos CM, et al. Estigma e preconceito: vivência dos usuários de crack. Rev. Latino-Am. Enfermagem [internet]. 2016 [acesso em 2020 maio 19]; 24(e2680):1-7. Disponível em: https://www. scielo.br/pdf/rlae/v24/pt_0104-1169-rlae-0852-2680. pdf.

17. Pombo MF. Da recusa à demanda de diagnóstico: novos arranjos da medicalização. Arq. bras. psicol. 2017; 69(3):5-20. 
18. Cardoso FM, Campos GW. Aprendendo a clínica do sofrimento social: narrativas do internato na Atenção Primária à Saúde. Ciênc. Saúde Colet. 2020; 25(4):1251-1260.

19. Leal EM, Ferrari IF. A realidade social brasileira e o retrocesso na Saúde Mental. Rev. latinoam. psicopatol. fundam. 2019; 22(3):421-438.

20. Moncrieff J. Antipsychotic maintenance treatment: time to rethink? PLoS med. [internet]. 2015 [acesso em 2020 maio 19]; 12(8):e1001861. Disponível em: https:// www.ncbi.nlm.nih.gov/pmc/articles/PMC4524699/.

21. Brasil. Resolução no 32 de 14 de dezembro de 2017. Estabelece as Diretrizes para o Fortalecimento da Rede de Atenção Psicossocial (RAPS). Brasília, DF: Ministério da Saúde, 2017.

22. Brasil. Ministério da Saúde. Nota Técnica $n^{\circ} 11 / 2019$. Esclarecimentos sobre as mudanças na Política Nacional de Saúde e nas diretrizes na Política Nacional sobre drogas. Brasília, DF: Ministério da Saúde, 2019.
23. Nóbrega MPSS, Venzel CMM, Sales ES, et al. Ensino de Enfermagem em Saúde Mental no Brasil: perspectivas para a atenção primária à saúde. Texto contexto - enferm. [internet]. 2020 [acesso em 2020 maio 19]; 29:e20180441. Disponível em: https://www. scielo.br/scielo.php?script=sci_abstract\&pid=S0104$-07072020000100315 \& \operatorname{lng}=$ en\&nrm=iso\&tlng=pt.

24. Carvalho PAL, Malhado SCB, Constâncio TOS, et al. Cuidado humano à luz da fenomenologia de Merleau-Ponty. Texto contexto enferm. [internet]. 2019 [acesso em 2020 maio 19]; 28:e20170249. Disponível em: https://www.scielo.br/scielo.php?script=sci_arttext \&pid=S010407072019000100605\&lng=pt\&nrm=iso $\&$ tlng=pt.

Received on 09/07/2019

Approved on 05/05/2020

Conflict of interests: non-existent

Financial support: non-existent 